ИЗВЕСТИЯ АКАДЕМИИ НАУК ЭСТОНСКОИ ССР. ТОМ 32 Химия. 1983, N. 1

Ene SIIGUR, Viive JÄRVE, T. NEUMAN,

A. TARA, J. SIIGUR

\title{
NERVE GROWTH FACTOR IN SNAKE VENOMS
}

(Presented by E. Lippmaa)

Nerve growth factor (NGF) is the name given to a group of proteins which specifically stimulate the growth and differentiation of sympathetic and embryonic sensory nerve cells. The earliest observations led to the discovery that mouse sarcoma 180 and other tumors produce NGF [1]. The most abundant source of NGF so far elucidated is the adult male mouse salivary gland $\left[{ }^{2}\right]$. Further studies revealed the NGF activity in the venoms of poisonous snakes $\left[{ }^{3,4}\right]$.

We have found NGF in the venoms of the following snakes which inhabit in the territory of the USSR: Vipera lebetina, V. ursini, Echis carinatus, Vipera berus and Agkistrodon halys (Table). In detection of

Levels of NGF activity in various snake venoms

\begin{tabular}{l|c}
\hline \multicolumn{1}{c|}{ Venom } & $\begin{array}{c}\text { The amount of venom required } \\
\text { to give standard response, } \\
\mu \mathrm{g} / \mathrm{ml}\end{array}$ \\
\hline & $\begin{array}{c}\text { Vipera lebetina turanica } \\
\text { V. ursini }\end{array}$ \\
V. berus & $1.7-3.3$ \\
Echis carinatus & $0.6-1.7$ \\
Agkistrodon halys & $0.6-1.3^{*}$ \\
& $0.6-1.0$
\end{tabular}

* Determined in the fourth gel filtration fraction from Sephadex G-100 column.

NGF activity we have used an in vitro bioassay with 8 -day chick embryonic sensory ganglia. After $18-24 \mathrm{~h}$ of incubation at $37^{\circ} \mathrm{C}$ in plasma clot hanging drop cultures an optimal NGF concentration elicits the uniform outgrowth of a «halo» of nerve fibres $\left[{ }^{5}\right]$. Levels of activity are expressed as the minimum concentration of $\mathrm{NGF}$ protein required to produce an accepted standard response.

The NGF from $V$. lebetina venom has been purified by the following two-step scheme:

1. A solution of crude venom $(5 \mathrm{~g})$ was passed down a column $(4.8 \times 140 \mathrm{~cm})$ of Sephadex G-100 (superfine, Pharmacia Fine Chemicals, Uppsala) equilibrated with $0.2 \mathrm{M}$ ammonium acetate, $\mathrm{pH} 6.5$ (flow rate $13 \mathrm{ml} / \mathrm{h}$ ).

2. The active fourth fraction from the Sephadex column was subjected to ion-exchange chromatography on CM-cellulose (Whatman CM-52) in 0.05 $\mathrm{M}$ ammonium acetate, $\mathrm{pH} 5.5$. A linear buffer gradient to $0.5 \mathrm{M}$ ammonium acetate was used for elution. 
The protein with $0.05-0.1 \mu \mathrm{g} / \mathrm{ml}$ specific activity $(\sim 30$ times of purification) was eluted with the last peak from $\mathrm{CM}$-cellulose (in $\sim 0.4 \mathrm{M}$ ammonium acetate). The preparation had detectable arginine esterase activity (about $1-1.5 \mathrm{u} / \mathrm{mg}$, with benzoyl arginine ethyl ester by the method described in $\left.\left.{ }^{6}\right]\right)$. The lyophilized NGF preparation was used in purity tests and physicochemical studies.

Analytical isoelectric focusing at $\mathrm{pH}$ interval 9-11 revealed four protein bands with $\mathrm{pI}$-s between 9.5 and 10.5 . The four protein bands with NGF and arginine esterase activities were identified also in preparative isoelectric focusing in Sephadex G-75 at the $\mathrm{pH}$ interval $9-11$. The data obtained point to a molecular heterogeneity of the $V$. lebetina venom NGF.

Passage of NGF through a calibrated Sephadex G-100 column at pH 7.5 (0.05 M Tris- $\mathrm{HCl}, 0.1 \mathrm{M} \mathrm{KCl}$ ) gave a symmetrical peak, corresponding to approximate molecular weight 35,000 . NGF from $V$. lebetina venom was stable in the $\mathrm{pH}$ range $3-11$ and upon treatment with $8 \mathrm{M}$ urea at $\mathrm{pH} 4.5$. The material can be stored at $4^{\circ}$ for months without appreciable loss of activity. It retains full activity by heating $20 \mathrm{~min}$ at $70^{\circ}$, but loses it after boiling the protein for $20 \mathrm{~min}$ at $100^{\circ}$.

In some properties ( $\mathrm{pI}$, molecular weight) the $V$. lebetina venom NGF is similar to NGF from $V$. russelli venom [ $\left.{ }^{7}\right]$. The concentration level of the highly purified NGF from $V$. lebetina venom in $\mathrm{mg}$ protein per $\mathrm{ml}$ required to produce standard response on the 8-day chick embryonic ganglia was about 10 times higher than that for $7 \mathrm{~S} \mathrm{NGF}$ from mouse submaxillary gland («Sigma» N 3006, lot 61F-05291).

The authors are indebted to A. Aaviksaar for helpful discussion and valuable suggestions regarding this work.

\section{REFERENCES}

1. Bueker, E. D. Implantation of tumors in the hind limb field of the embryonic chick and developmental responses of the lumbosacral nervous system. - Anat. Rec., 1948, 102, 369-390.

2. Cohen, S. Purification of a nerve growth promoting protein from the mouse salivary gland and its neurocytotoxic antiserum. - Proc. Natl. Acad. Sci. USA, 1960, 46, $302-311$.

3. Cohen, S. Purification and metabolic effects of a nerve growth promoting protein from snake venom. - J. Biol. Chem., 1959, 234, N 5, 1129-1137.

4. Hogue-Angeletti, R. A., Bradshaw, R. A. Nerve Growth Factors in Snake Venoms. In: Handbook of Experimental Pharmacology. Berlin-Heidelberg-New York, $1979,52,276-294$.

5. Levi-Montalcini, R., Meyer, H., Hamburger, $V$. In vitro experiments on the effects of mouse sarcomas 180 and 37 on the spinal and sympathetic ganglia of the chick embryo. - Cancer Res., 1954, 14, N 1, 49-57.

6. Schwert, G. W., Takenaka, Y. A spectrophotometric determination of trypsin and chymotrypsin. - Biochim. biophys. Acta, 1955, 16, 570-575.

7. Pearce, F. L., Banks, B. E. C., Banthorpe, D. V., Berry, A. R., Davies, H. H. S., Vernon, $C$. A. The isolation and characterization of nerve growth factor from the venom of Vipera russelli. - Eur. J. Biochem., 1972, 29, N 3, 417-425.

Academy of Sciences of the Estonian SSR, Institute of Chemical Physics and Biophysics

Academy of Sciences of the Estonian SSR,

Experimental Plant of Organic Synthesis and Bioproducts of Institute of Chemistry
Received

August 8, 1982 
Ene SIIGUR, Viive JARVE, T. NEUMAN, A. TARA, J, SIIGUR

\section{NÄRVIKASVUFAKTOR MAOMURKIDEST}

Artiklis on määratud närvikasvufaktori sisaldus mõningate NSV Liidu territooriumil elavate madude mürgis ning esitatud gürsa mürgist eraldatud närvikasvufaktori füüsikaliskeemilised andmed.

Эне СИИГУР, Вийве ЯРВЕ, Т. НЕУМАН,

A. ТАРА, Ю. СИИГУР

\section{ФАКТОР РОСТА НЕРВНОИ ТКАНИ ИЗ ЯДОВ ЗМЕИ}

В статье определены содержания фактора роста нервной ткани (ФРНТ) в некоторых ядах змей, обитающих на территории СССР. Представлены данные о выделении ФРНТ из яда гюрзы и его физико-химическая характеристика. 